\title{
Validation of Social Skills Measurement Tools for Special Needs Student
}

\author{
Farida Kurniawati \\ Universitas Indonesia
}

\begin{abstract}
The adaptation process for measurement of special needs student's social skills in inclusive primary schools was reported in this study. The Social Skills Improvement System was tested on 108 students aged 612 years. Social skills measurement include seven dimensions, that are empathy, cooperation, assertiveness, communication, self-control, participation, and responsibility. The adaptation process includes translation, back-translation, and expert judgment. Legibility tests then were conducted on 10 students with special needs. Reliability test shows that the measurement has an Alpha value of 0.833. Confirmatory Factor Analysis is done to see the loading factor of each item in the measuring instrument for students with special needs in inclusive primary schools. It was found that 24 items (three items with a loading factor below the good value is preserved) in the instrument had a factor loading ranging between 0.04-0.70 (RMSEA $=0.063, \mathrm{IFI}=0.89$ and GFI $=0.80)$. Based on these results, it can be concluded that SSIS measuring instruments that have been adapted into Indonesian is valid and reliable to measure the social skill of special need primary students. The implications of the study findings are discussed for future research.
\end{abstract}

Keywords: Adaptation, primary school, social skills. special need students

\section{Background}

The development of special needs student's social skills in inclusive schools is one of the goals of the implementation of inclusive education. The development of this aspect is possible to experience by special needs student given that in the inclusion setting they get the opportunity to interact with peers who do not have special needs. It was found that good social skills would support the establishment of good friendships quality and better academic achievements. On the other hand, the lack of social skills influences academic achievement and the development of aspects, such as selfconcept and self-esteem (Lee, 2005). Therefore it is important to know and develop the social skills possessed by students.

Gresham and Elliot (1984) define social skills as behaviors that are learned and socially accepted, which makes a person able to interact effectively and avoid unwanted social responses. Social skills are considered as the main aspects that are important in interacting with the social environment (Gresham \& Elliot, 2008). Social skills are defined by Gesten and Weissberg
(1986) as specific patterns of behavior that are learned and can be observed, both in verbal and nonverbal forms and can be done to influence others. In addition, Merrell and Gimpel (1998, in Hupp, LeBlanc, Jewell, \& Warnes, 2009) also define social skills based on combining several definitions of social skills. They defined social skills as specific behaviors that are learned including initiation and response-, that can increase social reinforcement, have an interactive and specific nature in certain situations, and can be targeted for interventions.

According to Gresham and Elliot (2008), social skills consist of seven dimensions including Cooperation, Communication, Empathy, Assertion, Engagement, Responsibility, and Self Control. Cooperation is explained as working behavior simultaneously with other people to achieve the same goal. The first dimension, Cooperation, describes the individual's desire to help or work together with others. Cooperation is shown through behavior such as helping others, sharing, and obeying rules and directives. The second dimension, Communication, is defined as behavior or the process of exchanging thoughts, opinions, or 
information, both verbally, written, and with sign language. Communication is shown by alternating behavior when speaking, making eye contact while talking, using the right tone of voice and gesture, saying "thank you" after being helped, and saying "please" when asking for help.

Empathy is the third dimension, which is defined as identification and/or understanding of the situation, feelings, thoughts, attitudes, and motives experienced or possessed by others. In other words, empathy is the ability to imagine the feelings of others and understand the mood that is being felt by others. Empathy is shown by respecting and noticing others feelings and points of view. Meanwhile, the fourth dimension, Assertive, is defined as behavior defending oneself or defending what is right. In addition, assertiveness is also explained as behavior conveying statements that are usually delivered without certain support or reason. Assertiveness is shown by the behavior of asking information to others, introducing oneself, and responding to the behavior of others. Participation as a fifth dimension is defined as behavior involving others and oneself in an activity, as well as sharing in group activities. Participation is indicated by behavior such as following ongoing activities, inviting others to join in ongoing activities, initiating conversation, showing the ability to make friends, and interacting well with others.

The sixth dimension, responsibility, is explained as the ability to make moral or rational decisions for oneself and to account for one's own behavior. Responsibility indicates the quality or state of an individual to be trusted or reliable. Responsibility is shown by behavior showing attention to work and showing the ability to communicate with adults. The last dimension, self-control, is explained as behavior controlling or limiting oneself in taking action and controlling emotions or staying calm when feeling angry, afraid, happy, or sad. Self-control is indicated by giving the right response behavior when in conflict and non-conflict situations.

Social skills are one of the important factors that influence the quality of friendship. Students with low social skills have a low quality of friendship characterized by a small number of close friends, as well as perceptions of having low support and closeness from close friends (Berndt, 2002). Social skills involve the ability to respond to other people, cooperate, initiate conversations, and understand the feelings and points of view of others. Social skills are the main aspects that underlie the interactions undertaken in social relations (Gresham \& Elliot, 2008). Students who further develop communication skills, empathy, and good cooperation tend to establish friendships that are closer and more stable than students who do not develop these skills (Rose, 2015). As with students in general, social skills are also important for students with special needs for their social life in school (Rose, 2015).

Gresham (2008), proposes that there are various methods that can be used in measuring social skills, such as direct systematic observation, behavioral rating scale, role-play, and various other assessment procedures. The behavioral rating scale can be assessed by the teacher or parent to report the students' social behavior based on a number of specific criteria (Hupp, LeBlanc, Jewell, \& Warnes, 2009). Besides being filled by teachers or parents, the behavioral rating scale can also be in the form of self-report. On a self-report behavior rating scale, individuals report their thoughts and views on their own social behavior (Hupp, LeBlanc, Jewell, \& Warnes, 2009). The behavioral rating scale is the method of measuring social skills most often used because it is considered as an effective method of describing social skills based on observations of specific criteria of oneself or others (Gresham \& Elliot, 2008).

Gresham and Elliot (2008) developed a measuring tool named The Social Skills Improvement System (SSIS) that has been used to measure social skills in children without special needs in various age ranges. Considering the importance of social skills in students with special needs, it is necessary to develop a similar tool that is able to measure this ability in a population of children with special needs. The existence of these measuring instruments is expected to help in providing information about the social development of students with special needs, which can be one of the benchmarks of the successful implementation of inclusive education. Therefore the purpose of this study was to adapt the social skills measurement tool based on The Social Skills Improvement System (SSIS). The scale used in this measuring instrument is a Likert scale with choices of answers A (false), B (not always true), C (true), and $\mathrm{D}$ (very true) with the range of A-D scores, $1-4$.

\section{Methodology}

Cite this as:

Kurniawati, Farida. Validation of Social Skills Measurement Tools for Special Needs Student. Indonesian Journal of Disability Studies (IJDS).2019: Vol. 6(1): PP 119 - 127. 


\subsection{Respondent}

There are two data collection in this study, pilot study and field study. The pilot study was conducted as part of the initial process of the instrument adaptation into Indonesian. The sampling technique used in the pilot study was nonprobability sampling using convenience sampling. Respondents were children who were studying in elementary school.

After obtaining the final results of the instrument using the Indonesian language that is suitable for elementary school students, researchers tested item samples for the context of elementary school students with special needs. In this field study, the sampling technique used in the sample of elementary school students with special needs is the nonprobability sampling method using purposive sampling. Purposive sampling was carried out to obtain individual samples whose criteria were predetermined (Cozby \& Bates, 2012). The following is a further explanation of the pilot study and field study.

\section{a. Pilot Study}

Respondents in the pilot study were 416 regular students who came from inclusive elementary schools in the Depok area and had friends with special needs. Age of respondents is in the range of 6-12 years.

\section{b. Field Study}

Respondents in the field study in this study were 108 elementary school students with special needs from 5 areas of Jakarta. They are in the age range of 612 years, and only have one type of special need (not double type).

\subsection{Procedures and Analysis Techniques}

In the process of adapting this

instrument, the steps taken are:

\section{a. Translation and Back Translation stage}

At this stage, the researcher conducts the language transfer process of instruments into Indonesian. Subsequently, the instrument is back translated to English to ensure the accuracy of the language transfer process in Indonesian that had been done previously.

\section{b. Expert Judgment}

Expert judgment is conducted on several academics and practitioners in the field of Special Education and Educational Psychology. Based on the input received, a reduction in the number of items in the measuring instrument is made. The original 46 items were reduced to 27 items.

\section{c. Instrument's Trial}

Instrument's trial begins with the readability test process. Readability tests were carried out on seven children with special needs consisting of children with Asperger, sensory disorders, and ADHD. The next stage is conducting Confirmatory Factor Analysis (CFA) on the SSIS instrument. CFA is done to test construct validity, to find out whether the items in the SSIS instrument actually measure the theoretical. CFA testing is carried out using data taken from 416 regular students in inclusive elementary schools in Depok. The selection of respondents in the CFA test was based on the consideration that the number of children with special needs was low. The CFA results show that from all SSIS items, there are three items that have a low loading factor. These items include " Ketika saya marah / sedih, saya memperlihatkan kepada orang lain (When I am angry / sad, I show others)" with a factor loading value of -0.01 , item "Saya memberitahu orang lain ketika saya diganggu (I tell others when I am disturbed)" with a factor loading value of 0.17 , and item "Saya dapat menerima ketika orang lain tidak setuju dengan saya (I can accept when people others disagree with me) "with a factor loading value of 0.16 . The items were decided to be removed so that the total number of items was 24 items.

Furthermore, in the field study involving 108 students with special needs, trials were carried out using alpha coefficients to see the reliability of the instrument. In addition, corrected item total correlation analysis was also conducted to see the validity of each item 
in describing the construct of social skills. Reliability test using alpha coefficient shows that the measuring instrument has good reliability with alpha coefficient value of 0.87 which can be said to be good according to Gravetter and Forzano (2012). In addition, the value of the corrected item from 24 items also has an $r$ value that is good according to Gravetter and Forzano (2012), which is above 0.3 .

\section{Result and Discussion}

\subsection{Pilot Study}

Table 1. Respondents Demography Description

\begin{tabular}{|l|l|l|l|}
\hline $\begin{array}{l}\text { Demographis } \\
\text { Data }\end{array}$ & Category & Frequency & Percentage \\
\hline \multirow{5}{*}{ Sex } & Male & 203 & 48.80 \\
\cline { 2 - 4 } & Female & 213 & 51.20 \\
\hline \multirow{5}{*}{ Age } & Total & 416 & 100 \\
\hline & 8 years & 36 & 8.65 \\
\cline { 2 - 4 } & 9 years & 70 & 16.82 \\
\cline { 2 - 4 } & 10 years & 47 & 11.29 \\
\cline { 2 - 4 } & 11 years & 223 & 53.60 \\
\hline & 12 Years & 40 & 100 \\
\cline { 2 - 4 } & & & \\
\hline & Total & 416 & \\
\hline & & & \\
\hline
\end{tabular}

In the table above, based on sex, it appears that female respondents have a higher percentage than male $(51.20 \% ; n=213)$. It was also known that the respondents were at most 11 years old with a percentage of $53.60 \%(\mathrm{n}=223)$ and at least 8 years old with a percentage of $8.65 \%(n=36)$.

\section{Instrument's Validity and Reliability Test in Children without Special Needs}

Furthermore, statistical tests were carried out to see the value of validity and reliability of the instrument adapted into Indonesian to a group of elementary school students without special needs. The reliability test results show an Alpha

Cite this as:

Kurniawati, Farida. Validation of Social Skills Measurement Tools for Special Needs Student. Indonesian Journal of Disability Studies (IJDS).2019: Vol. 6(1): PP 119 - 127. coefficient of 0.8. Anastasi and Urbina (2007) stated that the Alpha coefficient value for adequate reliability testing must be above 0.6 .

Next is to test construct validity using Confirmatory Factor Analysis (CFA). The CFA results show that there are three items in the measuring instrument that do not represent the construct so they need to be eliminated. Hair, Black, Babin, and Anderson (2010) stated that for factor analysis testing with the number of respondents above 350 people, the factor loading value needed to significantly contribute to the latent variable is 0.3 . The following is Table 2 which explains the results of the analysis with Confirmatory Factor Analysis.

Table 2. Confirmatory Factor Analysis Test Results

\begin{tabular}{|c|c|c|}
\hline No & Items & $\begin{array}{l}\text { Factor } \\
\text { Loading } \\
\text { score }\end{array}$ \\
\hline 1 & $\begin{array}{l}\text { Saya memaafkan orang lain } \\
\text { ketika mereka meminta maaf }\end{array}$ & 0.63 \\
\hline 2 & $\begin{array}{l}\text { Saya menjaga barang (alat } \\
\text { tulis) teman agar tidak rusak }\end{array}$ & 0.43 \\
\hline 3 & $\begin{array}{l}\text { Ketika meminta bantuan dari } \\
\text { orang lain, saya mengucapkan } \\
\text { kata "tolong" }\end{array}$ & 0.48 \\
\hline 4 & $\begin{array}{l}\text { Saya merasa tidak enak (tidak } \\
\text { nyaman) ketika orang lain } \\
\text { bersedih }\end{array}$ & 0.32 \\
\hline 5 & $\begin{array}{l}\text { Saya bergantian ketika } \\
\text { berbicara dengan orang lain }\end{array}$ & 0.49 \\
\hline 6 & $\begin{array}{l}\text { Ketika saya marah / sedih, } \\
\text { saya memperlihatkan kepada } \\
\text { orang lain }\end{array}$ & -0.01 \\
\hline 7 & $\begin{array}{l}\text { Saya melakukan apa yang } \\
\text { disuruh oleh guru }\end{array}$ & 0.60 \\
\hline 8 & $\begin{array}{l}\text { Saya mudah/gampang } \\
\text { memiliki teman }\end{array}$ & 0.34 \\
\hline 9 & $\begin{array}{l}\text { Saya tidak mudah marah / } \\
\text { menahan marah ketika diejek } \\
\text { (diganggu, dijahili, diledek) } \\
\text { teman }\end{array}$ & 0.46 \\
\hline
\end{tabular}




\begin{tabular}{|c|c|c|}
\hline 10 & $\begin{array}{l}\text { Saya mengikuti peraturan } \\
\text { sekolah }\end{array}$ & 0.65 \\
\hline 11 & $\begin{array}{l}\text { Saya mengajak teman-teman } \\
\text { saya untuk melakukan } \\
\text { berbagai kegiatan bersama } \\
\text { dengan saya }\end{array}$ & 0.41 \\
\hline 12 & $\begin{array}{l}\text { Saya menceritakan diri saya } \\
\text { dengan jujur }\end{array}$ & 0.64 \\
\hline 13 & $\begin{array}{l}\text { Saya melakukan apa yang } \\
\text { benar tanpa harus disuruh }\end{array}$ & 0.51 \\
\hline 14 & $\begin{array}{l}\text { Saya tersenyum } \\
\text { atau melambaikan tangan } \\
\text { kepada orang yang saya temui }\end{array}$ & 0.53 \\
\hline 15 & $\begin{array}{l}\text { Ketika guru sedang mengajar } \\
\text { di kelas, saya mendengarkan }\end{array}$ & 0.70 \\
\hline 16 & $\begin{array}{l}\text { Saya bermain dengan teman- } \\
\text { teman saya }\end{array}$ & 0.42 \\
\hline 17 & $\begin{array}{l}\text { Saya mengerjakan PR tepat } \\
\text { waktu (tidak terlambat) }\end{array}$ & 0.69 \\
\hline 18 & $\begin{array}{l}\text { Saya memberitahu orang lain } \\
\text { ketika saya diganggu }\end{array}$ & 0.17 \\
\hline 19 & $\begin{array}{l}\text { Saya menghibur teman saya } \\
\text { yang sedang sedih }\end{array}$ & 0.55 \\
\hline 20 & $\begin{array}{l}\text { Saya ikut bermain dengan } \\
\text { teman saya yang sedang } \\
\text { bermain }\end{array}$ & 0.40 \\
\hline 21 & Saya menepati janji & 0.64 \\
\hline 22 & $\begin{array}{l}\text { Saya mengucapkan terima } \\
\text { kasih ketika sudah dibantu }\end{array}$ & 0.57 \\
\hline 23 & $\begin{array}{l}\text { Ketika orang lain mengganggu } \\
\text { saya, saya tidak marah }\end{array}$ & 0.35 \\
\hline
\end{tabular}

\begin{tabular}{|l|l|l|}
\hline 24 & $\begin{array}{l}\text { Saya bekerjasama dengan baik } \\
\text { bersama teman-teman sekelas }\end{array}$ & 0.55 \\
\hline 25 & $\begin{array}{l}\text { Saya mengakui kesalahan saya } \\
\text { di hadapan orang lain }\end{array}$ & 0.49 \\
\hline 26 & $\begin{array}{l}\text { Saya meminta bantuan ketika } \\
\text { memerlukan pertolongan }\end{array}$ & 0.52 \\
\hline 27 & $\begin{array}{l}\text { Saya dapat menerima ketika } \\
\text { orang lain tidak setuju dengan } \\
\text { saya }\end{array}$ & 0.16 \\
\hline
\end{tabular}

With the removal of 3 items (items number 6, 18 and 27), the factor loading value of each item is at $0.32-0.70$. This test shows that the social skills instrument adapted into Indonesian in the respondent group of elementary school students without special needs can be said to be valid and reliable.

\subsection{Field Study}

Table 3. Respondent Demographic Description

\begin{tabular}{|c|c|c|c|}
\hline $\begin{array}{l}\text { Demographis } \\
\text { Data }\end{array}$ & Category & Frequency & $\begin{array}{l}\text { Percenta } \\
\text { ge }\end{array}$ \\
\hline \multirow{3}{*}{ Sex } & Male & 74 & 68.5 \\
\hline & Female & 31 & 31.5 \\
\hline & Total & 108 & 100 \\
\hline \multirow{7}{*}{ Age } & 7 years & 2 & 1.9 \\
\hline & 8 years & 4 & 3.7 \\
\hline & 9 years & 19 & 17.6 \\
\hline & 10 years & 26 & 24.1 \\
\hline & 11 years & 36 & 33.3 \\
\hline & 12 years & 21 & 19.4 \\
\hline & Total & 108 & 100 \\
\hline
\end{tabular}

Cite this as:

Kurniawati, Farida. Validation of Social Skills Measurement Tools for Special Needs Student. Indonesian Journal of Disability Studies (IJDS).2019: Vol. 6(1): PP 119 - 127. 


\begin{tabular}{|l|l|l|l|}
\hline \multirow{5}{*}{$\begin{array}{l}\text { Special } \\
\text { Needs }\end{array}$} & $\begin{array}{l}\text { Learning } \\
\text { Disability }\end{array}$ & 2 & 11.1 \\
\cline { 2 - 4 } & $\begin{array}{l}\text { Slow } \\
\text { Learner }\end{array}$ & 91 & 1.9 \\
\cline { 2 - 4 } & $\begin{array}{l}\text { Orthopedic } \\
\text { Disabled }\end{array}$ & 2 & 84.2 \\
\cline { 2 - 4 } & Deaf & 1 & 1.9 \\
\cline { 2 - 4 } & Total & 108 & \\
\cline { 2 - 4 } & & & \\
\hline
\end{tabular}

Based on the demographic data from the table above, it can be seen the description of respondents. Based on gender, the study was dominated by male respondents with a percentage of $68.5 \%(n=74)$. The respondents were at most 11 years old with a percentage of $33.3 \%(n=36)$ and at least 7 years old with a percentage of $1.9 \%$ $(\mathrm{n}=2)$. The majority of special needs types are slow-learner with a percentage of $84.2 \%(n=91)$

\section{Instrument's Validity and Reliability Test in Student with Special Needs}

The results of statistical tests show that the value of the reliability of the instrument as a whole is good referring to the limits stated by Kerlinger and Lee (2005), where to be considered reliable the alpha coefficient need to be in the range 0.7 to 0.8 . When viewed in each dimension, there are two dimensions that have good reliability, namely the Cooperation and Participation dimensions. Meanwhile, the other five dimensions have reliability values, which are included in the satisfying category when referring to the theories of Kerlinger and Lee (2005). The following is Table 4, which explains the results of reliability testing using the Cronbach Alpha technique.

Table 4. Reliability Rest

\begin{tabular}{|l|l|l|}
\hline Variable & Dimension & $\begin{array}{l}\text { Alpha } \\
\text { Coefficient }\end{array}$ \\
\hline Social Skills & & 0.87 \\
\hline & Communication & 0.66 \\
\hline
\end{tabular}

\begin{tabular}{|l|l|l|}
\hline & Cooperation & 0.72 \\
\hline & Assertion & 0.64 \\
\hline & Empathy & 0.66 \\
\hline & Responsibility & 0.65 \\
\hline & Engagement & 0.71 \\
\hline & Self Control & 0.62 \\
\hline
\end{tabular}

Furthermore, the validity test is done by using two ways, by analyzing the corrected item total correlation to see internal validity and confirmatory factor analysis (CFA) test to see construct validity.

Referring to the theory proposed by Cohen and Swerdlik (2005) the results of the validity test show that the items in the instrument have a good corrected item total correlation value with a coefficient $\mathrm{r}$ above 0.3 which indicates that the items measure the construct. While the results of testing using confirmatory factor analysis show there are four items having a value below the significant CFA limit (i.e. items number 1, 4, 7 and 13). Table 5, shows the comparison of the validity test results using corrected item total correlation and CFA analysis.

Tabel 5. Validity Test Result Comparison

\begin{tabular}{|l|l|l|l|}
\hline No & Items & $\begin{array}{l}\text { Corrected } \\
\text { Item -Total } \\
\text { Correlation }\end{array}$ & $\begin{array}{l}\text { Factor } \\
\text { Loadin } \\
g \\
\text { Score( } \\
\text { CFA) }\end{array}$ \\
\hline 1 & $\begin{array}{l}\text { Saya memaafkan } \\
\text { orang lain ketika } \\
\text { mereka meminta maaf }\end{array}$ & 0.354 & 0.17 \\
\hline 2 & $\begin{array}{l}\text { Saya menjaga barang } \\
\text { (alat tulis) teman agar } \\
\text { tidak rusak }\end{array}$ & 0.422 & 0.31 \\
\hline 3 & $\begin{array}{l}\text { Ketika meminta } \\
\text { bantuan dari orang }\end{array}$ & 0.357 & 0.33 \\
\hline
\end{tabular}




\begin{tabular}{|c|c|c|c|}
\hline & $\begin{array}{l}\text { lain, saya } \\
\text { mengucapkan kata } \\
\text { "tolong" }\end{array}$ & & \\
\hline 4 & $\begin{array}{l}\text { Saya merasa tidak } \\
\text { enak (tidak nyaman) } \\
\text { ketika orang lain } \\
\text { bersedih }\end{array}$ & 0.335 & 0.04 \\
\hline 5 & $\begin{array}{l}\text { Saya bergantian ketika } \\
\text { berbicara dengan } \\
\text { orang lain }\end{array}$ & 0.452 & 0.31 \\
\hline 6 & $\begin{array}{l}\text { Saya melakukan apa } \\
\text { yang disuruh oleh guru }\end{array}$ & 0.522 & 0.52 \\
\hline 7 & $\begin{array}{l}\text { Saya mudah/gampang } \\
\text { memiliki teman }\end{array}$ & 0.343 & 0.13 \\
\hline 8 & $\begin{array}{l}\text { Saya tidak mudah } \\
\text { marah / menahan } \\
\text { marah ketika diejek } \\
\text { (diganggu, dijahili, } \\
\text { diledek) teman }\end{array}$ & 0.462 & 0.7 \\
\hline 9 & $\begin{array}{l}\text { Saya mengikuti } \\
\text { peraturan sekolah }\end{array}$ & 0.651 & 0.30 \\
\hline 10 & $\begin{array}{l}\text { Saya mengajak teman- } \\
\text { teman saya untuk } \\
\text { melakukan berbagai } \\
\text { kegiatan bersama } \\
\text { dengan saya }\end{array}$ & 0.433 & 0.63 \\
\hline 11 & $\begin{array}{l}\text { Saya menceritakan diri } \\
\text { saya dengan jujur }\end{array}$ & 0.354 & 0.43 \\
\hline 12 & $\begin{array}{l}\text { Saya melakukan apa } \\
\text { yang benar tanpa } \\
\text { harus disuruh }\end{array}$ & 0.333 & 0.35 \\
\hline 13 & $\begin{array}{l}\text { Saya tersenyum } \\
\text { atau melambaikan }\end{array}$ & 0.521 & 0.29 \\
\hline
\end{tabular}

\begin{tabular}{|c|c|c|c|}
\hline & $\begin{array}{l}\text { tangan kepada orang } \\
\text { yang saya temui }\end{array}$ & & \\
\hline 14 & $\begin{array}{l}\text { Ketika guru sedang } \\
\text { mengajar di kelas, } \\
\text { saya mendengarkan }\end{array}$ & 0.442 & 0.37 \\
\hline 15 & $\begin{array}{l}\text { Saya bermain dengan } \\
\text { teman-teman saya }\end{array}$ & 0.421 & 0.41 \\
\hline 16 & $\begin{array}{l}\text { Saya mengerjakan PR } \\
\text { tepat waktu (tidak } \\
\text { terlambat) }\end{array}$ & 0.524 & 0.44 \\
\hline 17 & $\begin{array}{l}\text { Saya menghibur teman } \\
\text { saya yang sedang } \\
\text { sedih }\end{array}$ & 0.552 & 0.69 \\
\hline 18 & $\begin{array}{l}\text { Saya ikut bermain } \\
\text { dengan teman saya } \\
\text { yang sedang bermain }\end{array}$ & 0.452 & 0.34 \\
\hline 19 & Saya menepati janji & 0.641 & 0.53 \\
\hline 20 & $\begin{array}{l}\text { Saya mengucapkan } \\
\text { terima kasih ketika } \\
\text { sudah dibantu }\end{array}$ & 0.572 & 0.33 \\
\hline 21 & $\begin{array}{l}\text { Ketika orang lain } \\
\text { mengganggu saya, } \\
\text { saya tidak marah }\end{array}$ & 0.352 & 0.3 \\
\hline 22 & $\begin{array}{l}\text { Saya bekerjasama } \\
\text { dengan baik bersama } \\
\text { teman-teman sekelas }\end{array}$ & 0.554 & 0.52 \\
\hline 23 & $\begin{array}{l}\text { Saya mengakui } \\
\text { kesalahan saya di } \\
\text { hadapan orang lain }\end{array}$ & 0.439 & 0.44 \\
\hline 24 & $\begin{array}{l}\text { Saya meminta bantuan } \\
\text { ketika memerlukan } \\
\text { pertolongan }\end{array}$ & 0.422 & 0.34 \\
\hline
\end{tabular}

Cite this as:

Kurniawati, Farida. Validation of Social Skills Measurement Tools for Special Needs Student. Indonesian Journal of Disability Studies (IJDS).2019: Vol. 6(1): PP 119 - 127. 
The CFA test results showed the value of the Root Mean Square Error of Approximation (RMSEA) is 0.063 and the Comparative Fit Index (CFI) is 0.89. This shows the acceptable fit value of the proposed model ( $\mathrm{Hu} \&$ Bentler, 1999). Because of the small number of samples in the CFA test on this instrument, researchers also looked at the Incremental Fit Index (IFI) and the value of the Goodness of Fit Index (GFI) which was not influenced by the sample size (Forza \& Filipini, 1998). The test results show an IFI value of 0.89 and a GFI value of 0.80 . This shows that the SSIS instrument that has been adapted into Indonesian and tested on students with special needs can measure the construct of social skills in a distinctive manner.

\section{Conclusion and Discussion}

The results of the general description analysis of the respondents indicate that there is a balanced amount between male and female respondents in the pilot study conducted on regular children (students without special needs) in inclusive primary schools. When viewed by age, the majority of respondents in the pilot study were 11 years old. In contrast to the tests carried out on the pilot study, the majority of respondents in the field study were male. Similarly, with the pilot study, the majority of respondents in the field study were 11 years old. Furthermore, related to the characteristics that distinguish pilot samples and field studies, namely the types of special needs, the majority of respondents are slow learners.

Based on statistical tests using confirmatory factor analysis it was found that this instrument has 24 items with good factor loading so that it can be said that the 24 items have a significant contribution to each latent variable from the social skills construct. In other words, there are 24 valid items in measuring the construct of social skills. The reliability test shows that overall the measuring instrument has a very satisfying alpha coefficient when referring to the theory put forward by Kerlinger and Lee (2005) and Anastasi and Urbina (2007).

In addition, if reviewed in each dimension, two dimensions show very satisfactory reliability while the other five dimensions show satisfactory reliabi lity when referring to the theories of Kerlinger and Lee (2005).

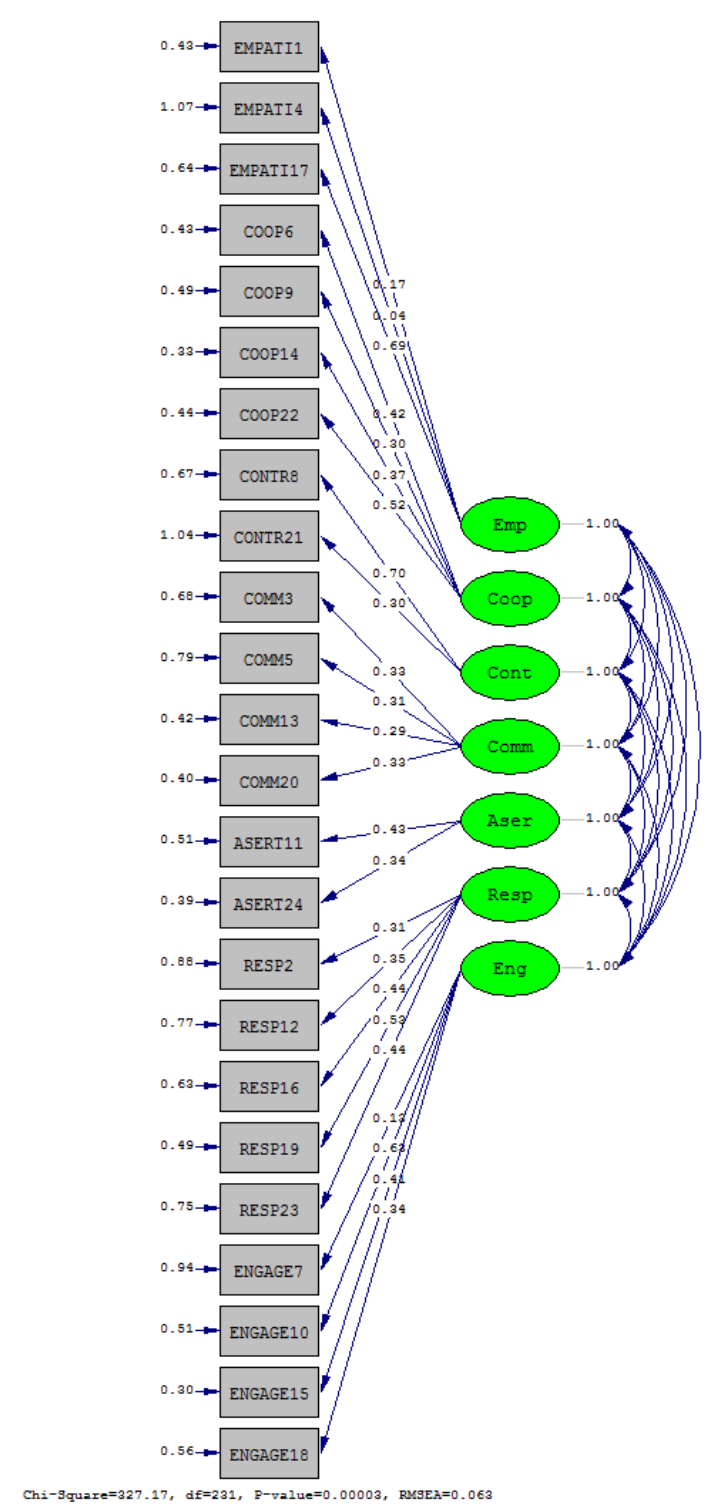

Fig 1. Instrument's Factor Analysis

Referring to Cohen and Swedlik (2005) regarding the limits of the $r$ value which describes the internal validity of the items in a particular measuring instrument-, the analysis of corrected item total correlation of this instrument shows that the items in the instrument are valid in measuring internal consistency with the item correlation coefficient value with the total score of the instrument greater than 0.3 .

Testing of construct validity with CFA shows that this instrument is valid in measuring the construct of social skills. Though there are four items that have a factor loading value below the valid limit, the researcher retains these items because if the items are deleted, the dimensions of Empathy will be erased.

There are several limitations in the process of adaptation to this instrument. One of them,

Cite this as:

Kurniawati, Farida. Validation of Social Skills Measurement Tools for Special Needs Student. Indonesian Journal of Disability Studies (IJDS).2019: Vol. 6(1): PP 119 - 127. 
related to the type of special needs of the students taken in the field study which tends to be homogeneous where the slow learner students number the most when compared to other special needs so that the research is less generalized to students with special needs in general. In addition, the number of respondents is highly recommended to be added as said by Gravetter and Forzano (2005) that the more the number of respondents in the study, the closer the sample to the population to be studied.

\section{References}

Cohen, R. J., \& Swerdlik, M. E. (2005), Psychological testing and measurement:An introduction to tests and measurement, McGrawHill, New York.

Forza, C., \& Filippini, R. (1998), “TQM impact on quality conformance and customer satisfaction: A causal model", International Journal of Production Economics, Vol. 55, Page $1-20$.

Gravetter, F. J., \& Forzano, L. B. (2012), Research methods for the behavioral science (4th ed.), Wadsworth Cengange Learning, Canada

Gresham, F.M., \& Elliot, S.N. (2008), Social skills improvement system-rating scales, MN: Pearson Assessments, Minneapolis.

Hair, J. F., Black. W. C., Babin. B. J., \& Anderson. R. E. (2010), Multivariate Data Analysis (7th ed.), Pearson Prentice Hall, New Jersey.
Hallahan, D.P., \& Kauffman, J.M. (2006), Exceptional children: Introduction to special education (10th ed.), Allyn \& Bacon, Boston.

Heiman, T.(2000), "Quality and quantity of friendship: Students' and teachers' perceptions", School Psychology International, Vol. 21 No. 3, Page 265-280.

Henninger, W.R.,\& Gupta, S.S. (2014), Excerpted from first steps to preschool inclusion: How to jumpstart your program wide plan, Brookes Publishing, USA.

Hildayani, R., Hadis, F.A., dan Tambunan, S.M. (2002). Peran kualitas attachment, usia, dan gender terhadap kualitas persahabatan. Tesis tidak dipublikasikan. Fakultas Psikologi, Universitas Indonesia, Depok.

Hu, L., \& Bentler, P. M. (1999), "Cutoff criteria for fit indexes in covariance structure analysis: Conventional criteria versus new alternatives", Structural Equation Modeling, Vol. 6, Page 1-55.

Kerlinger, F.N., \& Lee, H.B. (2005), Foundations of behavioral research (4th Ed.), Harcourt College Publishers, Orlando.

Koster, M., Pijl, S. J., Nakken, H., \& Van Houten, E. (2010), "Social participation of students with special needs in regular primary education in Netherlands", International Journal of Disability, Development and Education, Vol. 57 No. 1, Page 59-75.

Lee, S. W. (2005), Encyclopedia of school psychology, SAGE Publications, Inc., London. 